\title{
The Future of Electricity and Electricity as the Future: The Sociotechnical Imagination of Russian Electrical Engineers in the 19th Century ${ }^{1}$
}

\author{
Natalia Nikiforova \\ National Research University \\ Higher School of Economics (HSE) \\ Myasnitskaya 20 \\ Moscow 101990, Russia \\ Email: nvnikiforova@hse.ru
}

\begin{abstract}
This article examines Russian engineers' social imagination about the future through the professional discussions held at the electrotechnical congresses in the nineteenth century. Formulating the prospective future of the industry, the state and society was a collective endeavor, a process in which the identity and mission of engineers were crystallized. Through envisioning the future of technology and its role in the society, engineers revealed their cultural role as mediators between technological innovation, and both the wider public and the state. In order to better understand the manifestations of the shared cultural understandings of a desirable future and social order, the article resorts to Sheila Jasanoff's concept of sociotechnical imaginaries (Jasanoff \& Kim, 2015). The engineering community's sociotechnical imagination about electricity was shaped around the transformative possibilities of this technology. It was believed that electrical engineering was able not only to accelerate industrial production, but also to solve social, medical and cultural problems, thereby uniting the Russian Empire. Descriptions of the rational, comfortable and beautiful world of the electrified future overlapped in engineering discussions, journalism and science fiction. Positive scenarios emphasized the advantages of electrical engineering and bypassed the problems associated with electrification, constructing an idea of its inevitability. The electrical engineer became a kind of a new cultural hero, who knew how to make a working device or system, and also filled the task of linking the development of technology to the development of society.
\end{abstract}

1 The article was prepared within the framework of the HSE University Basic Research Program and funded by the Russian Academic Excellence Project '5-100'. 
Keywords: electrical engineering, electricity, future, science fiction, sociotechnical imaginaries, temporality

\section{Introduction}

In the nineteenth century, the Western European world became concerned about time-its acceleration, and the need to keep up with the pace of life and progress in general. Universal mechanical time gradually replaced traditional and natural cycles. A set of temporal ideas was formed: a sort of preoccupation with the future, which began to be regarded as a result of present and past actions (Brown et al., 2016); the discovery of history and of the future as unknown and beyond the control of religious powers (Koselleck, 2004, p. 22). Evolutionary theories highlighted the importance of the nexus of past and future (Bock von Wülfingen et al., 2015). The establishment of these new temporal regimes was largely connected with technological innovations-transport, communication technologies, and the creation of large technological systems that shaped specific "industrial time", productive and commodified (Adam, 1990). It seemed that time and space were accelerating and annihilating (Morus, 1998, pp. 194-198). The idea of speed was also one of the dominant concepts of time, and one of the most vivid symbols of speed was electricity racing through the wires (Kern, 2003, p. 114). Engineers were at the heart of these processes of technical transformation. They became a new type of scientist-practitioner and the new cultural heroes, whose mission was not only to create technological artifacts, but also to transform the society. Engineers were the key actors in setting the agenda for discussions on existing and future technologies.

The innovative technology that was introduced into production, households and urban space was electricity. The engineering community discussed the problems of the future, the significance of electrification in the future, and the role of engineers in transforming the present, as well as the new principles of engineering education. Reformed engineering education was supposed to provide new skills such as reasonable time management practices, and help turn engineers into a new type of professional — an agent of technological change and cultural transformation, and the carrier of ideas about the socio-technical future.

This article examines Russian engineers' social imagination about the future by focusing on professional discussions taken from the electrotechnical congresses of the nineteenth century. The period covered in the article is from the $1880 \mathrm{~s}$ 
(when the first public electric plants started to be constructed in Russia and the first attempts to formalize this process were introduced) to the 1910s (a period of active development of the electrical industry and of state participation in controlling it). Formulating the prospective future of the industry, the state and society was a collective endeavor, a process in which the identity and mission of engineering were crystallized. By envisioning the future of technology and its role in the society, engineers revealed their cultural role as mediators between technological innovations, the wider public and the state.

In order to better understand the manifestations of shared cultural understandings of a desirable future and social order, the current study resorts to the concept of sociotechnical imaginaries. This concept, suggested by Sheila Jasanoff, represents collective and stabilized visions of desirable futures attainable through advances in science and technology and helps unite the study of societal structure and perceptions with the studies of materiality and technology (Jasanoff \& Kim, 2015 , p. 2). Studying sociotechnical imaginaries also makes it possible to address the hopes and desires of a community and, at the same time, engage with technological systems, industrial projects and material artifacts. The article is dedicated to the temporal ideas that functioned within the community of Russian electrical engineers at the turn of the twentieth century, as well as their ideas about the future of the electrical industry, and its possibilities to improve society and the state. The research materials include the proceedings of the electrotechnical congresses of the nineteenth century, publications in electrotechnical journals intended for the experts, as well as those published in the popular press and science fiction.

\section{Historiography of the electrical imagination}

Contemporary research on the history of electrical engineering draws attention to the peculiar properties of electricity and electric energy as objects of research, observation, property and use. In the eighteenth century, experiments with electricity were a kind of a scientific spectacle, a performance indicating a cognitive interest in the absence of a direct practical application. In the nineteenth century, useful ways to apply electricity were discovered, including communication technologies, motor power, and lighting. The key agents of the creation and promotion of these new technologies were engineers and industrialists, who set the pace of technological development and determined the contours of future 
technical systems. However, as historical studies show, electrification is also a social process involving complex constellations of factors and solutions. The configuration of a technical system is influenced by many things-from the geographical landscape to the political context and user behavior.

Thomas P. Hughes was one of the first to demonstrate the development of the energy supply system as a social and political process (Hughes, 1983). He compared the history of early electrification in Chicago, Berlin and London. Energy systems are complex entities consisting of material artifacts, resources, people, and managerial relations. Hughes showed that power systems vary from country to country; in each particular place and at any given moment, the set of variables that affect the system is different. Hughes introduced the concept of 'technological style', which helped overcome the reductionist idea that technology is a simple application of science and economics.

Electrical networks and technologies may be perceived as resulting from a social and political vision, or as technological artifacts having significant cultural value. Vincent Lagendijk describes early twentieth century electrification projects as the "electrical imagination of Europe" (Lagendijk, 2008). Technical infrastructures within the projects, suggested by French and German engineers, were conceived as infrastructural substrates for European political integration. The projects envisaged the connection of major metropolitan areas and rational interaction between producers and consumers of electricity. Such engineering ideas inspired political leaders and research by the League of Nations on the inter-European production, distribution and exchange of electricity. "Europe" represented a unit of optimization, where energy resources and electricity demand could be rationalized to the maximum extent.

The German electrical network has been shown to be grounded in collectively developed ideals. Electrification was seen as having two different motives. The winning conception considered a highly centralized system with high-voltage plants and transmission lines. Another vision promoted a system supporting small-scale manufacturing and trade, which was a possible way of softening the effects of concentrated, large-scale production. Negotiations concerning the process of electrification included political, economic, and cultural values (Gilson, 1998). Beate Binder (1999) has shown mythological and allegorical representations as accompanying electrification and exemplifying a cultural promise of progress and modernization. 
Olivier Coutard (2001) described early rural electrification in France and the USA, highlighting the social and cultural motives behind this process. The creation of large-scale systems in both countries did not follow one predetermined scenario, since farmers had their own vision and interpretation of electrical technology, and also used a number of energy sources as alternatives to the centralized power systems. Coutard explains the state's motivation for rural electrification as a "modern imagination"- a rational step towards economic enhancement. Nevertheless, economic and functional reasons were supplemented and, in certain cases, replaced by symbolical values. Electrification was promoted as a symbol of social equality between the city and the countryside. The introduction of electricity was even perceived as a symbolic return of the debt owed to the countryside for providing the city with resources. Meanwhile, electrification was also seen as a way to tie people to the land and stop them from moving to the city. There was a certain paradox — state programs aspired to modernize the countryside and reduce the dependence of the rural population on the land; yet, at the same time it emphasized the preservation of specific rural values and attitudes toward the land and nature. According to Coutard, the fact that electrification promoters easily coped with such paradoxes confirms the imaginary nature of electrification motives, which could contravene pure rational economic logic (Coutard, 2001).

David Nye (1990) shows that the development of electrification in the USA was also wrapped into symbolic and utopian ideas. The new technology transformed city space, providing new feelings and new spatial experiences. Huge electrical illuminations at large political events and industrial expositions, according to Nye (1990), stimulated civic participation, created a shared national identity and taught people to love electricity.

Communities of electrical experts only began to form in the 1880s in Europe, the USA and other parts of the world. As Carolyn Marvin (1988) indicates, the notions of electrical engineers or electricians were still very vague, and the electrical community was less privileged and less respected, in comparison with mechanical and civil engineers. Marvin traces the shaping of the distinct professional identity of electrical engineers through their practices of dealing with professional texts and technical documentation.

The sociocultural aspects of early electrification in Russia have become the focus of some historical studies. By looking at science fiction, literature and popular scientific journals, Anindita Banerjee revealed the construction of the meanings of modernity in Russia, and especially of the transformative possibilities of 
electricity to enhance the social and moral dimensions of the Russian society (Banerjee, 2012). The author also highlights that the ideas of electricity shaped in the nineteenth century became the basis for the Soviet Bolshevik myth of electrification (Banerjee, 2011). The mythological aspects of Soviet electrification as a process of enlightenment, the accomplishment of social equality, and political renewal of the country were researched by Elena Zheltova (1996) and Natalia Nikiforova (2017).

The activity of engineering communities in the Russian Empire was investigated by Jonathan Coopersmith (1992), as a prehistory of the Soviet electrification project. Nikolai Simonov (2016) thoroughly reviewed statistical documents and showed that the electrotechnical industry in the Russian Empire was far more developed than what was later presented by the Soviet propaganda. He also gathered information about electrotechnical societies and electrotechnical education in nineteenth-century Russia.

The present article focuses on revealing engineers' imagination about electricity and an electrified future. Ideas about temporality, the flow of time, and accelerating the speed of science, production and life itself were prevalent in the technical and administrative discussions that took place at electrotechnical congresses. Electrical energy and electrical technology were the focal points regarding the future of the state, society and progress, in general.

\section{Electricity as the future and the future of electricity}

Electricity in the Russian Empire developed less quickly than in Europe and the USA; nevertheless, it slowly gained an active foothold. The latest studies show that, in terms of electrical energy production, Russia was not that backward. Historian Nikolai Simonov (2016), based on the "energy censuses" of the Ministry of Finance from 1906 to 1915, shows that Russia occupied the fourth place in the world in regard to electrical energy production. The Ministry of Finance investigated central and private power stations and calculated the aggregate capacity of the electrical industry. Electrotechnical congresses also worked on gathering statistical data on energy production and consumption. The congresses asked power plants to respond to a questionnaire, and later calculated the average capacity of urban and rural power plants. The congresses came to the conclusion that by 1910 , electricity was in use not only in large cities but also in rural 
areas. Based on these and other archival sources, Simonov found that early Soviet statistics purposely lowered the figures related to the electrical industry of the Russian Empire. In terms of power plant capacity, in 1916, Russia was twenty times inferior to the USA and four times inferior to Germany. At the same time, Russia produced the same amount of electrical energy as England, and more than France and Japan (Simonov, 2016, pp. 16-28).

Since the beginning of the nineteenth century, electricity in Russia was primarily used by the military, for telegraph, telephone and electrical mine firing purposes. Civic uses of electricity were also actively promoted and introduced since the 1870s - electric lighting, electric power in the production industry, and telegraph and telephone communication. Electric energy was considered a very promising and forward-looking technology, but at the same time it was still an unpredictable and relatively new field. The engineering community was concerned with how to support this young and vulnerable field, and help it to fully develop its potential for the society and the state.

Electrical engineers in Russia founded several professional societies-for instance, the Society of Engineers-Electricians of the Electrotechnical Institute (founded in 1892), and the Electrotechnical Society, which was founded by industrialists (1892). The most active of such societies was the VI Section of the Imperial Russian Technical Society (1878). Its activities were oriented towards uniting like-minded people. This group organized electrotechncial congresses and exhibitions, published the most famous professional journal, Elektrichestvo ('Electricity'), and popularized knowledge about electricity. The agenda for this society was elaborated within the electrotechnical congresses, initiated in 1899. The participants of these events were civic and military engineers, representatives of the state authorities, academia and industry. Before the Great October Revolution (1917), seven congresses were held. Specific technical themes (such as, for example, solutions for railway carriage coupling, engine design, and the use of electricity in various industrial spheres) were intertwined with wider questions related to the social meanings of technologies for the society and country, and had a conspicuous temporal perspective. Engineers conceptualized electricity as a serious component in the contribution of a desired and satisfactory future, presented the history of humanity through the linear development of energy consumption, and made assumptions about what the future with electricity would be like.

In the opening addresses of the congresses, speakers appealed to the past and inscribed electricity in the "big history book" of technology. The electrical engine 
was associated with modernity and considered the successor of the steam engine. Anatoli Smirnov, chair of the VI Section of the Technical Society, referred to a steam engine and a dynamo working on the same shaft as a major symbol of progress (Smirnov, 1899-1900, p. 127). At the same time, it was unclear what would become of electrical technology_engineers had to put all their efforts into helping their industry achieve the status it truly deserved. When presenters turned to the past in their speeches, they indicated that the contemporary electrical industry was shaped by a chain of previous situations and contingencies. Russian physicist and specialist in electrical measurement, N. G. Egorov, in his opening speech for the first electrotechnical congress said that "Volta passed into the hands of natural scientists a source of electricity, unaware that it would serve as a firm and indestructible bridge over an abyss that had long been lying between a magnet and an electrified body and seemed impassable" (Egorov, 1900, translated by the author). In the history of electric energy use and of technology in general, engineers observed clear linear development and succession. Moreover, they drew analogies between the fate of inventions and evolution in nature. A famous Russian engineer and philosopher of technology, Peter Engelmeyer, wrote about the struggle for the existence of technical inventions. According to Engelmeyer, "technical Darwinism" differed from nature only in that there was no autogenesis in nature, while technical creativity could make new types and classes of objects—for example, a dynamo (Engelmeyer, 1898, pp. 95-97).

The electric engine was described as a technical artifact which, in the future, would revolutionize technology, industry and labor, "saving for the people the only role of rational controller" (Smirnov, 1899-1900, translated by the author). A repetitive trope in engineers and scientists' texts was presenting the history of humanity as a history of energy. Russian physicist Nikolai Umov added the development of electricity to the historical timeline, beginning with the slavery era. Technological progress in this picture was a linear, infinite, unlimited forward movement, realized not only for the contemporaries, but for future generations (Umov, 1916, p. 448). As Peter Engelmeyer indicated, "technological thinking was teleology itself," a passage from thoughts to things. It seems that engineers forced the idea of goal setting, of a chain of interrelated processes and interconditionality on any phenomenon-from the workings of the mechanism to social processes and history itself.

Not only did progress move linearly, it was as if it were continuously accelerating, and the huge difference between the present and the past was often emphasized. In a brochure that promoted the need to electrify the Russian Empire, the author 
indicated that today's Russia was infinitely more distant from that of sixty years ago at the time of the Crimean War of 1853-1856. According to the author, in the future, the pace of life and progress would certainly accelerate more and more. He predicted that over the next sixty years our children and grandchildren would develop far beyond us. The pace of life had been tremendously boosted and continued to move at a progressive pace, with grandiose changes taking place over the course of one human life (Kekonomicheskomu osvobozhdeniyu Rossii, 1915, p. 23).

The congress participants emphasized that electrical technology would not only be able to ensure efficient and accelerated production, it would also solve social problems. For instance, water purification would help overcome the sanitary problems in crowded cities (Efron, 1902-1903), electricity would transform agriculture through the introduction of electrocultures, which grow faster (Pilsudskiy, 1904-1906), and special devices would be developed to help blind people read (Tyurin, 1902-1903).

An important and recurrent theme of the congresses was the popularization of electricity and persuasion of the wider public regarding the need for electrification. The new responsibility of engineers involved not only the creation of a working object or system, but also a concern about the creation of a market and the stimulation of trust. This is what the public activities of engineers were geared towards, through lectures, publications and exhibitions. Some mild means of persuasion were also effective, such as the imposing of comfortable tariffs to stimulate the usage of electricity — not only for lighting, but also for mechanical power used for household needs, which would level off electric power usage during the day (Rzhevskiy, 1902-1903). Autobiographies of engineers who graduated from the Saint-Petersburg Electrotechnical Institute also mention engineering specialists' additional educational, popularizing, and organizational activities. Pavel Voynarovsky, within the framework of his private activities, was an expert and a consultant, who participated in various projects, including the electric tram, and the reorganization of the telephone network in St. Petersburg. He also published extensively on the usage of electricity in everyday life and the conditions for developing the electrical industry in Russia. Vladimir Dmitriev gave lectures and published on issues related to the rational organization of central power stations. V. Blazheevsky translated foreign literature on electrical engineering (Avtobiografi..., 1905).

At the same time, the members of the electrotechnical field assessed it as a young, vulnerable and as yet unformed field, whose future was still unclear and which 
was completely dependent on the engineers. As engineer Smirnov stated, "with all its huge growth, electrical technology is still very young and doesn't have a fully established character" (Smirnov, 1899-1900, translated by the author). The young age of this field and the "obscurity of the limits of its application, the crude state of many of its spheres justifies the necessity of frequent meetings of its representatives" (Golytsyn, 1902-1903, translated by the author). The discussions at the congresses were dedicated to the consolidation of electrotechnics as a scientific and practical field. The participants were concerned with elaborating measurement standards and units, tariffs, terminology, norms and rules related to the setup and maintenance of electrical devices. Agreement on standards was necessary in order to stabilize the institutionalization of electric engineering as a self-sufficient and powerful field. Besides, standardization was important in the commercial respect for the effective delivery of services, as well as for users' comfort and trust. These discussions were especially prominent in terms of the standardization of electrical measurement and electrical meters-these questions were discussed at numerous congresses. Speakers emphasized the idea that electrical meters had a great influence on the industry; users frequently complained about the meters' inaccuracy. According to P. Kovalev, the meters served as mediators between the manufacturer of energy and the user, and their flaws provoked the public's mistrust towards electricity itself. The supply and consumption of electricity was further complicated by the fact that, until 1899, there were no Russian laws indicating that electrical energy was an object of property. In the new 1899 regulations on weights and measures, it was mentioned, for the first time, that the Main Office of Weights and Measures would be responsible for testing electrical meters. In 1902, the Senate within the framework of one court case explained that the theft of electrical energy would be considered a crime (Kovalev, 1902-1903, p. 54). According to a congress speaker, P. Kovalev, electrical energy would become an object of property and value, protected by the law, which would allow electricity to spread faster (Kovalev, 1902-1903, p. 60).

Electrotechnical congresses and the VI Section of the Imperial Technical Society worked on statistics and gathered data about the presence of private and central power stations in Russian cities, about the economic organization of these stations, and about accidents connected with electricity. It was also important to clearly define what electrical engineering and electrical technology in Russia consisted of.

For the engineering community, the potential of electrical energy for the development of the state was extremely important. Considering this topic, 
engineers undertook the roles of economists, managers and politicians. Engineers emphasized the nationwide importance of electrical enterprises, which had not been fully acknowledged. They lamented that electrical engineering in Russia was in a poor state, and needed careful development and protection from foreign capital and products. V. Svinitsky mentioned that foreign machines were cheaper than Russian ones, and suggested that the situation could be improved by increasing customs duties. This would allow Russian electrotechncial enterprises to work for the internal market. As a result, "the development of electrotechnical and copper industries would put the economic life of the people of Russia in more favorable conditions, the development of other connected industries, and of industry in general, which will make Russia a country that not only consumes, but also produces, while raising the exchange-value of the ruble. This will promise a leading economic status among the civilized countries for Russia, which it deserves for its territory and the genius of the Russian people" (Svinitskiy, 1902-1903, p. 133, translated by the author). The question of a foreign presence in the electrical industry became especially critical during World War I, when technological and energy-related self-sufficiency were equated to political sovereignty. Foreign capitalists were described as "taking the vital nerve of our industry and agriculture-electric energy - into their own hands, and being capable of causing harm and losses" (Svinitskiy, 1902-1903, p. 133, translated by the author).

Engineers were concerned with the fact that electrical plants were underestimated by city administrations and district councils, which treated them as regular commercial firms with no special social significance. Electric plants were subject to high taxes (calculated by capital expenditure, not by income). Engineer Iakov Perelman called it "a tax on the progress of technology, a brake on the development of better forms of production and transmission of driving and light energy, paralyzing the development of popular labor in all its diverse forms" (Perelman, 1914, p. 232, translated by the author).

\section{Literary scenarios of the electrified future}

At the end of the nineteenth century, when the developmental pathways of the electrical industry were not yet predetermined or obvious, it was interesting for many to envision an electrified world of the future, where social problems, such as overpopulation, poor hygiene, undereducation, and impossibly hard labor 
would be solved. Sketches of an electrified future in engineering discussions resonated with fantastic and utopian literary texts that gained popularity at the time.

For example, a utopian novel by Nikolai Shelonsky, entitled $V$ mire buduschego ('In the world of the future'; 1892), describes the Russian Arctic at the end of the third millennium, when electricity is so developed that people eat, drink and wear it, as well as use it as a source of energy, medicine, and for transport and communication:

Huge buildings were flashing with millions of sparks, they stood out from the sea and surrounding greenery with their towers rising skyward. The ribbon of the river, familiar to our eyes, was shining with silver and snaking capriciously, the arcs of the bridges seemed to hang in the transparent blueness of the air. Plots of cultivated land in the shape of equilateral squares and elongated strips appeared yellow because of golden ears of wheat or they appeared to be dark blue, standing out from the greenery of the trees, here and there. From the foothills of the rocks the road meandered among motley, fragrant flowering carpets, towering among them were giant trees and hanging alleys stretching in all directions. (Shelonskiy, 2014[1892], pp. 416-417, translated by the author)

In the future of Russia, according to Shelonsky, instead of noisy, dirty cities there would be gardens; distances would not exist; it would be possible to read one another's thoughts; and all interaction would be rational and calm. And all this would be made possible thanks to a kind of metatechnology of electricity.

This description echoes the report from a 1912 business trip to Germany by Professor A. N. Antsyforov. According to the author of the brochure $K$ ekonomicheskomu osvobozhdeniiu Rossii putem elektrifikatsii ee territorii ('Towards the economic liberation of Russia through the electrification of its territory'), the description of modern electrified rural areas in Germany from this report may give the Russian reader a rough idea of the future:

Among the fields covered with wheat and grass, poles with porcelain insulators and wires are stretched along the roads cutting through the fields with white highway ribbon in all directions... The most unsightly dwellings are illuminated by incandescent bulbs with metal threads. The same bulbs light milking cows and feeding pigs. The bellows of the village blacksmith feeds the fire using a small electric motor, which, if necessary, also drives 
The Future of Electricity and Electricity as the Future:

The Sociotechnical Imagination of Russian Electrical Engineers in the 19th Century

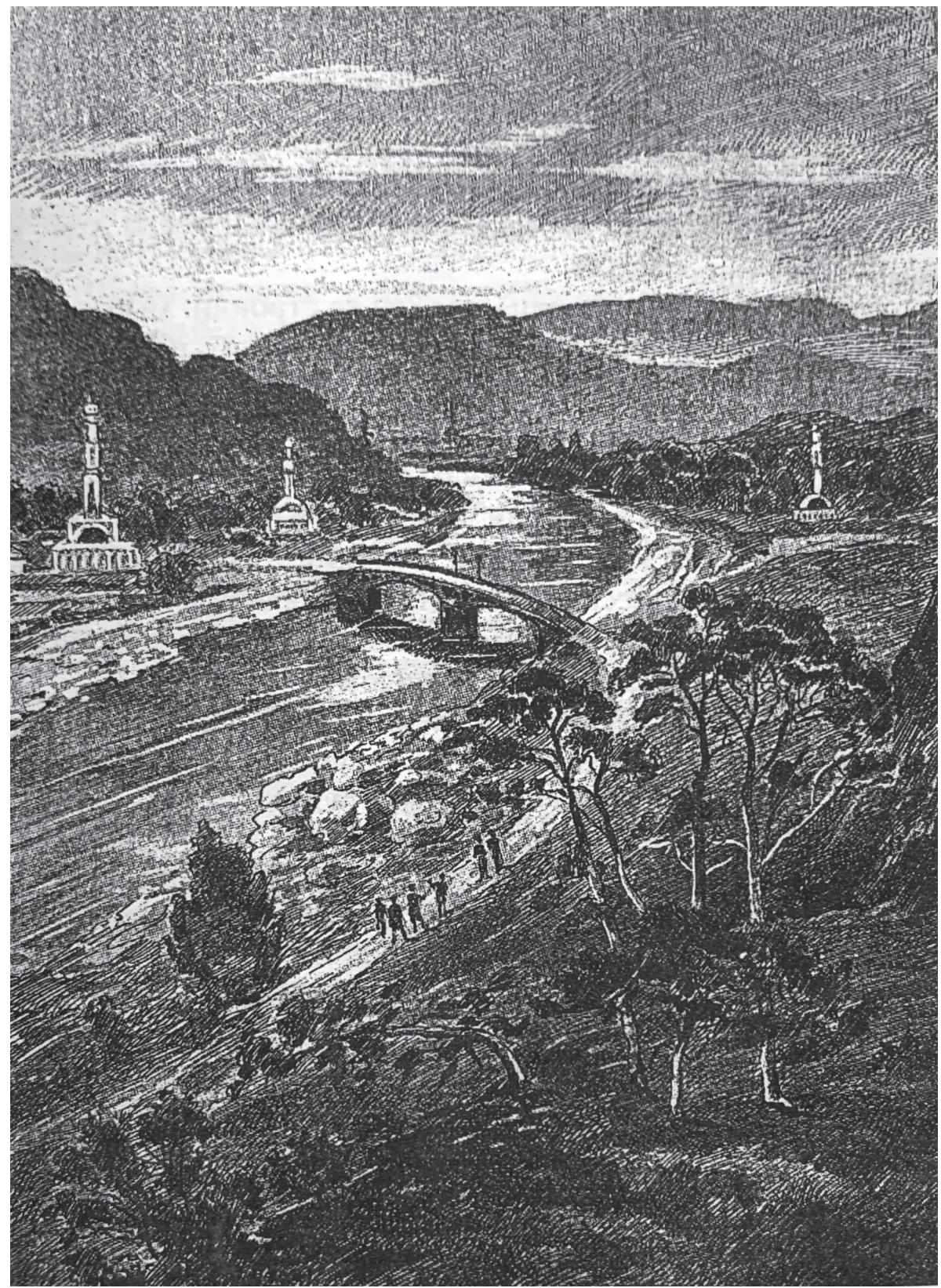

Figure 1. Illustration by A. Gofman showing the valley in the Russia of the future for the novel $V$ mire buduschego ('In the world of the future') by Nikolai Shelonsky (originally published in 1892, reprinted in 2014). 


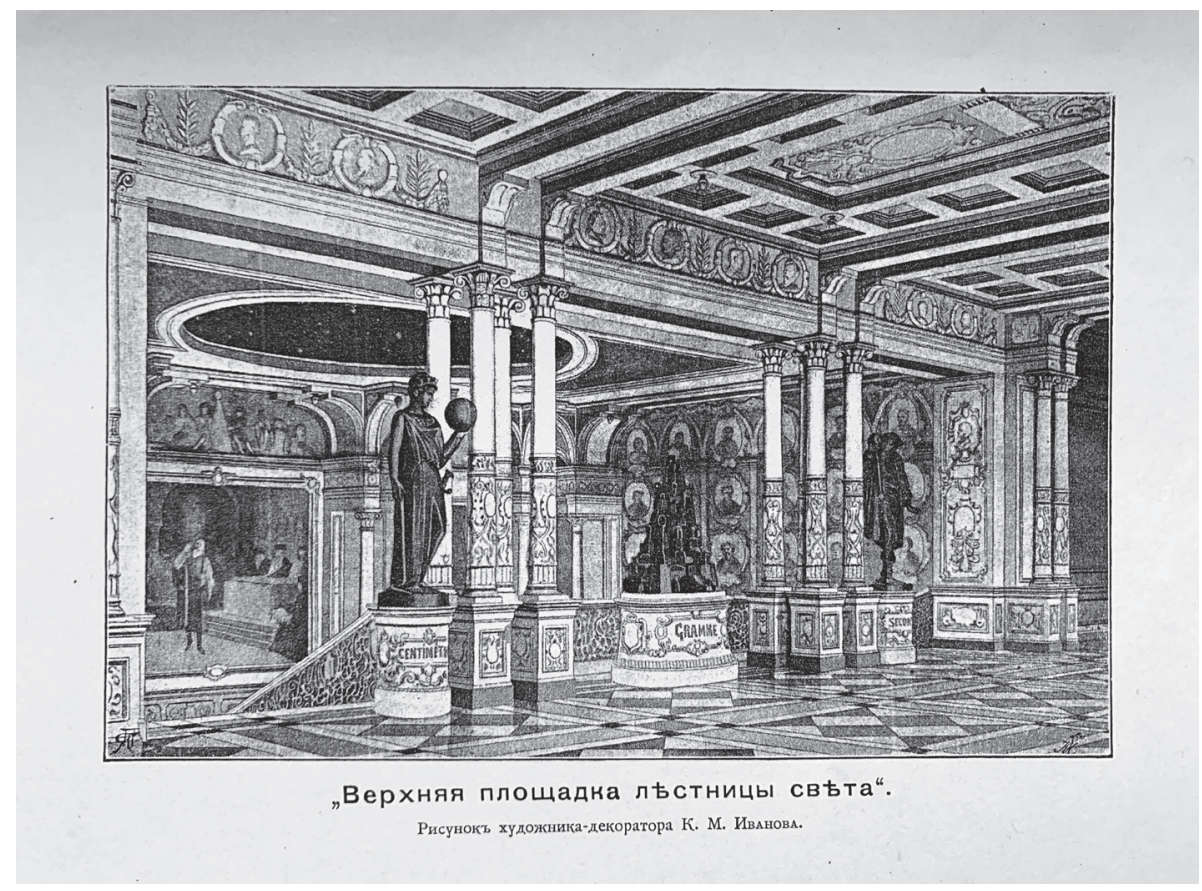

Figure 2. Upper hallway of the Staircase of Light. Picture by artist K. M. Ivanov for the novel Ne byl', no i ne vydumka ('Not a true story, but not a fiction') by Vladimir Chikolev (1895).

both the sharpener and the drill. The carpenter cuts out and saws his planks and bars with extraordinary speed using the same obedient slave, an electric motor. (Buhgeim, 1915, p. 11, translated by the author)

Western countries were seen as benchmarks for modernization, and at the same time as "figures of imagination"- abstract fictional spaces where a technological paradise had already been achieved. Partly for Russia, technological renewal was something that had already happened elsewhere, something that needed to be repeated and reproduced while it was finding its own way.

At the turn of the twentieth century, fantastic novels about the possible future were written not only by writers but also by engineers. For example, Thomas Edison created a draft of a futuristic novel about electricity (Daugherty, 2018). In Russia, the most striking example of a literary engineer was Vladimir Chikolev, an engineer, inventor, founder and editor of the journal Elektrichestvo ('Electricity'), and a popularizer of technology. He wrote several stories and 


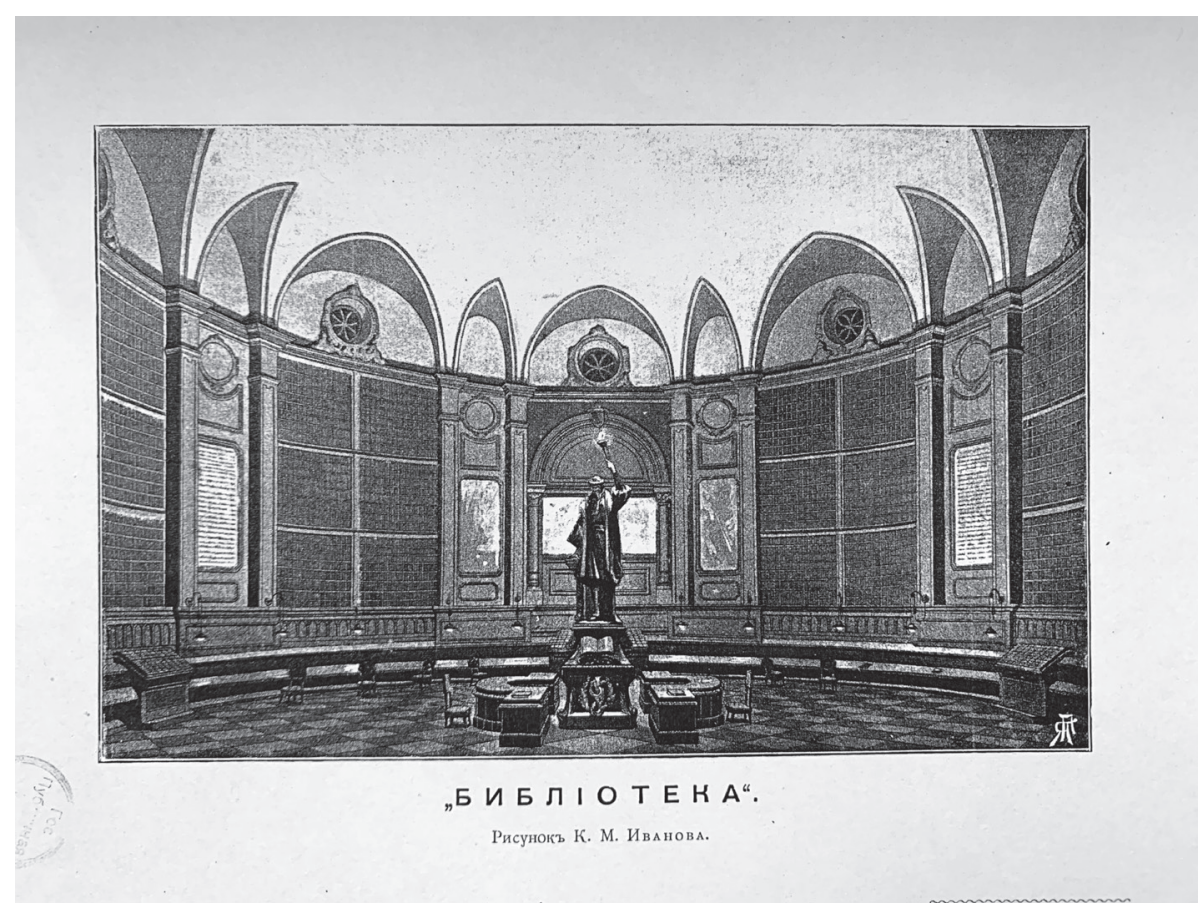

Figure 3. Library. Picture by K. M. Ivanov for the novel by Vladimir Chikolev (1895).

one big novel, in which he discussed the advantages of electricity over other technologies and reflected on possible scenarios for the future development of electrical engineering. It was no coincidence that technical experts devoted their time to literary experiments - in fantastic and utopian literature, the idea that the future is connected with electricity was carefully constructed-this is where the inevitability of electrification and its role in life and industry were spelled out.

Chikolev, in his novel Ne byl', no i ne vydumka ('Not a true story, but not a fiction'; Chikolev, 1895), described a gathering of like-minded peoplescientists and engineers-in a grand palace, which a rich eccentric owner had decided to turn into an international institute of electricity. The luxurious palace was equipped with the latest laboratories and was full of advanced electrical equipment. No servants were necessary, as everything was performed by electrical devices. Engineers and scientists from different countries could stay there to develop their ideas. The novel describes a congress held by this institute. The main part of the text consists of transcripts of the participants' speeches about new technological developments, new theories, the social importance of electricity and its future development. This part of the text 
resembles, or rather recreates, the proceedings of the real electrotechnical congresses in which Chikolev himself took part.

The novel describes several performances and plays that focused on the use of electricity-the transmission of the orchestra's performance with the help of telephones and microphones, visual projections, remote fireworks, electrochemical experiments-all of which really reflects how the public perceived electrical technology in reality at the time. The novel speaks of the consistent successive development and accumulation of electrical technology that would serve humanity in the future, which once again reflects the idea of linear progress. Electricity was compared to a child, and its development was compared to moving into adulthood. This trope neutralized the fear of the novelty of electricity, and presented it as something that needed to be cared for, rather than something frightening and dangerous. The electricians' speeches in the novel are very similar to those of the actual Russian electrotechnical congresses, where inventions and the possible future of electricity were also discussed.

The description of the bright, rational, comfortable and serene world of the electrified future shifted people's attention from the problems that accompanied electrification in the present, and gradually shaped the idea of the inevitability and necessity of electrification.

\section{Conclusion: juxtaposition of imaginaries}

Engineers were not alone in their visions about electricity and the future, as various interpretations were expressed also by different stakeholders and political actors, who proposed their ideas about technology and its influence on the future state. The first pragmatic uses of electrical power at the beginning of the nineteenth century were performed by the military and the navy. For the military, electricity was seen as an important strategic resource necessary to enhance the army's possibilities to attack and defend the state. Electrical technology, from this perspective, was not intended for wide public usage and the transformation of everyday life.

Broader applications of electricity in the second half of the nineteenth century (electric lighting, power plants, electric communication) were implemented under the supervision of the Ministry of Internal Affairs, which provided administrative and police control in terms of the construction and maintenance 
of electric plants. This ministry also introduced the rules for running the wires and organizing technology for electric lighting in 1885. A special Technical and Construction Committee was organized under the auspices of the Ministry of Internal Affairs to control and inspect the construction of electrical sites. Until the very end of the Russian Empire, the possibility for the Ministry of Internal Affairs to be responsible for the development of the entire electrotechnical industry was discussed. In their view, electricity was perceived as a potentially dangerous force in need of a complex set of taming mechanisms. Their main rival and eventual winner was the Ministry of Trade and Industry that managed to gain administration over the electrical technology, leaving only telephone and telegraph communication for the Ministry of Internal Affairs. This decision was secured in an agreement between the two ministers Vsevolod Shakhovskoy (Minister of Trade and Industry) and Alexander Protopopov (Minister of Internal Affairs) signed in $1916 .{ }^{2}$ Thus, the understanding of electrical technology as a public good won over treating it as a dangerous entity in need of restriction.

The Ministry of Railways also had its views on the prospects of electricity. All the waterways within the Empire were under the charge of this ministry; thus, they licensed the construction of hydroelectric stations and were responsible for the electrification of the railways. This was finally confirmed in 1916 (Grischenko \& Zinovatniy, 2008, p. 55). The intentions of this ministry made the development of electrical technology subject to the development of the transportation system, which was seen as strategically relevant, as an industry capable of modernizing and consolidating the Empire.

In the civil law sense, electricity still had to be considered a property, due to its inconceivable nature and elusive materiality. It was only at the very turn of the twentieth century that it was recognized that electricity, although immaterial, existed and was undoubtedly an economic product, which shared all the features of property in the sense of the law (Grischenko \& Zinovatniy, 2008, p. 20).

Local councils and city administrations perceived power plants as ordinary commercial enterprises and introduced burdensome local taxes (Perelman, 1914). This view of electricity and electrical enterprises imposed too many restrictions and did not take into account its social and state potential.

2 Soglasitel'naya zapiska Ministra Torgovli i Promyshlennosti i upravlyayushchego Ministerstvom Vnutrennikh Del № 7311 July 5, 1916 [Conciliation Note by the Minister of Trade and Industry and the Manager of the Ministry of Internal Affairs No. 7311 July 5, 1916] in Grischenko \& Zinovatniy, 2008, pp. 179-181. 
Distinct visions concerning the electrical industry expressed by different ministries and institutions treated electricity as a valuable internal resource, as a means to enhance transportation networks, as a potentially dangerous force that needed to be tamed and controlled, and as a commercial asset. These visions, however, were fragmentary and dealt with past or contemporary problems and challenges. At the same time, the engineering community saw electricity as a sort of meta-technology, capable of revitalizing industry and culture-a technology in which the future was encoded.

Electrical engineers were interested in giving integrity to the electrical community, in forming an industry from diverse specialists, investing in activities that were servicing other areas, and in formulating and communicating to the public the wider sociocultural meanings associated with electrical engineering and electricity. The key questions about the future, opportunities and limitations of electrical engineering were discussed at the congresses organized by the VI Department of the Imperial Russian Technological Society. Experts believed that they should make serious efforts and join forces to ensure that electrical engineering would develop from a fragile, young industry and achieve the status it deserved. To make electrical engineering a full-fledged scientific and technical field, the VI Department collected statistics on the distribution of electricity in the Russian Empire, and on the construction and management of electric plants. One of the rhetorical strategies to consolidate the status and substantiate the importance of electrical engineering was to integrate it into the "big" linear history of technology, in which each new invention continued the chain of those that had preceded it, and promoted the progress of society. The development of technology was even compared to evolution in nature, and the development of electricity was treated as a natural course of progress. Another step towards the formation of an integral field was the development of uniform electrical terminology, units of measurement, standards of installation and guidelines for operating devices. An important theme of the congresses was the relationship with the society and consumers - specialists collected recommendations on the most productive ways of introducing new products, persuading and increasing trust in electricity from the public and city authorities. Codes of ethics were discussed, prescribing the attitude towards society as a whole and towards other members of the professional community. The potential of electricity for the development of the state was significant for the engineering community, and the political sovereignty and place of the Russian Empire among other world powers were connected with technological independence. 
The engineering community's sociotechnical imagination about electricity was shaped around the transformative possibilities of this technology. It was believed that electrical engineering was not only able to accelerate industrial production, but also to solve social, medical, and cultural issues, and to unite the empire. Descriptions of the rational, comfortable, beautiful world of the electrified future were presented in discussions about engineering, journalism and science fiction. Positive scenarios emphasized the advantages of electrical engineering and bypassed the problems associated with electrification, constructing an idea of its inevitability. The electrical engineer became a kind of a new cultural hero, who knew how to make a working device or system, and also had the task of linking the development of technology to the development of society.

Both technocratic and metaphysical visions of electricity, which were grounded within the engineering community of the Russian Empire, would later form the basis of the early Soviet approach to electrification as a full-blown industry, with its own development plan and its messianic capabilities to transform the society and culture together with the revitalization of the national industry (on Soviet electrification as a social and messianic project see Banerjee, 2011; Nikiforova, 2017). Many of the engineers who were active at the electrotechnical congresses, and who occupied important positions in electrical enterprises during the imperial period (for instance, V. Dmitriev, M. Shatelen, G. Graftio, G. Krzhizhanovsky), would later contribute to the conception and performance of GOELRO 3 . Early Soviet technoculture was imbued with futurist and utopian meanings, which conceptually relied on the vision of the late nineteenth century engineers.

\section{References}

Adam, B. (1990), Time and Social Theory, Cambridge: Polity Press.

Avtobiografii.. (1905), Avtobiografi okonchivshikh kurs v Elektroteknicheskom institute 1889-1904 [Autobiographies of graduates of the course at the Electrotechnical Institute 1889-1904], St. Petersburg: Electrotechnical Institute.

Banerjee, A. (2011), 'Electric origins: from modernist myth to Bolshevik utopia,' in O. Asselin, S. Mariniello \& A. Oberhuber (eds.) L'Ėre électrique—The Electric Age, Ottawa: University of Ottawa Press.

Banerjee, A. (2012), We Modern People: Science Fiction and the Making of Russian Modernity, Middletown, CT: Wesleyan University Press.

3 GOELRO_-the first-ever Soviet plan for national economic recovery and development and the transliteration of the Russian abbreviation for 'State Commission for Electrification of Russia'. 
Binder, B. (1999), Elektrifizierung als Vision: Zur Symbolgeschichte einer Technik im Alltag, Tübingen: Tübinger Vereinigung für Volkskunde.

Bock von Wülfingen, B.; Brandt, C.; Lettow, S. \& Vienne, F. (2015), 'Temporalities of reproduction: practices and concepts from the eighteenth to the early twenty-first century,' History and Philosophy of the Life Sciences, vol. 37, no. 1, pp. 1-16. https://doi.org/10.1007/s40656-015-0059-9

Brown, N.; Rappert, B. \& Webster, A. (2016), Contested Futures: A Sociology of Prospective Techno-Science, New York: Routledge. https://doi.org/10.4324/9781315259420

Buhgeim, E. O. (1915), Kekonomicheskomu osvobozhdeniyu Rossii putem elektrifikatsii ee territorii [Towards the economic liberation of Russia through the electrification of its territory], Moscow: Yakovlev Printing House.

Chikolev, V. (1895), Ne byl', no i ne vydumka [Not a true story, but not a fiction], St. Petersburg: P. Babkin Printing House.

Coopersmith, J. (1992), The Electrification of Russia, 1880-1926, Ithaca: Cornell University Press.

Coutard, O. (2001), 'Imaginaire et developpement des reseaux techniques. Les apport de l'histoire del'électrification rurale en France et aux Etats-Unis,' Réseaux, vol. 5, no. 109, pp. 76-94. https://doi.org/10.3917/res.109.0076

Daugherty, G. (2018), 'Thomas Edison's forgotten sci-fi novel,' Smithsonian Magazine, 3 January. Retrieved from www.smithsonianmag.com/history/thomas-edisonsforgotten-sci-fi-novel-180967672/ [accessed 20 Jan 2020]

Efron, B. (1902-1903), 'Sterilizaciya vody ozonom po sisteme Simens i Gal'ske' [Sterilization of water with ozone by Siemens and Galske system], Trudy Vtorogo Vserossiiskogo elektrotekhnicheskogo s"ezda [Proceedings of the Second All-Russian Electrotechnical Congress], vol. 3, pp. 81-110.

Egorov, N. (1900), 'Stoletie elektricheskogo toka. Rech', proiznesennaya na otkrytii S" ezda' [The century of electric current. The speech delivered at the opening of the Congress], Elektrichestvo [Electricity], nos. 1-2, pp. 8-12.

Engelmeyer, P. (1898), Tekhnicheskii itog XIX veka [The technical result of the XIX century], Moscow: K. Kaznacheev Printing House.

Gilson, N. (1998), 'Rationale Kalkulation oder prophetische Vision?' in K. Pitzner (ed.) Elektrizität in der Geistesgeschichte, Bassum: Verlag für Geschichte der Naturwiss und der Technik.

Golytsyn, V. (1902-1903), 'Rech' predsedatelya II Elektrotekhnicheskogo s"ezda' [Introductory speech of the II Electrotechnical Congress], Trudy Vtorogo Vserossiiskogo elektrotekhnicheskogo s"ezda [Proceedings of the Second All-Russian Electrotechnical Congress], vol. 1, pp. 100-102.

Grischenko, A. \& Zinovatniy, P. (2008), Energeticheskoe pravo Rossii (Pravovoe regulirovanie elektroenergetiki $v$ 1885-1918) [Energy Law of Russia (Legal regulation of electric power industry in 1885-1918)], Moscow: Yurist. 
The Future of Electricity and Electricity as the Future: The Sociotechnical Imagination of Russian Electrical Engineers in the 19th Century

Hughes, T. P. (1983), Networks of Power: Electrification in Western Society, 1880-1930, Baltimore, MD: Johns Hopkins University Press.

Jasanoff, S. \& Kim, S.-H. (2015), Dreamscapes of Modernity: Sociotechnical Imaginaries and the Fabrication of Power, Chicago: University of Chicago Press. https://doi.org/10.7208/chicago/9780226276663.001.0001

Kern, S. (2003), The Culture of Time and Space, 1880-1918, Cambridge, MA: Harvard University Press.

Koselleck, R. (2004), Futures Past: On the Semantics of Historical Time, New York: Columbia University Press.

Kovalev, P. (1902-1903), 'O pravilakh dlya poverki schetchikov' [About the rules for verification of meters], Trudy Vtorogo Vserossiiskogo elektrotekhnicheskogo s"ezda [Proceedings of the Second All-Russian Electrotechnical Congress], vol. 1, pp. 50-62.

Lagendijk, V. C. (2008), Electrifying Europe: the Power of Europe in the Construction of Electricity Networks, Amsterdam: Aksant.

Marvin, C. (1988), When Old Technologies Were New. Thinking About Electric Communication in the Late Nineteenth Century, New York: Oxford University Press.

Morus, I. R. (1998), Frankenstein's Children: Electricity, Exhibition, and Experiment in Early-Nineteenth-Century London, Princeton, NJ: Princeton University Press.

Nikiforova, N. (2017), 'Lampochka Il'icha i simvolicheskie aspekty v propagande elektrifikatsii' [Ilyich bulb and symbolic aspects in promoting electrification], Obshchestvo. Sreda. Razvitie [Society. Environment. Development], no. 4, pp. 102-109.

Nye, D. (1990), Electrifying America: Social Meanings of a New Technology, 1880-1940. Cambridge, MA: MIT Press.

Perelman, I. (1914), 'K voprosu ob oblozhenii central'nykh elektricheskikh stancii obshchestvennogo pol'zovaniia' [On the question of the taxation of public central power plants], Elektrichestvo [Electricity], no. 5, pp. 232-233.

Pilsudskiy, E. (1904-1906), 'K voprosu o primenenii elektrichestva v agrikul'ture' [On the application of electricity in agriculture], Trudy Tretiego Vserossiiskogo elektrotekhnicheskogo s"ezda [Proceedings of the Third All-Russian Electrotechnical Congress], vol. 3, pp. 309-312.

Rzhevskiy, V. (1902-1903), 'Proekt tarifa za elektricheskuyu energiyu, otpuskaemuyu central'nymi elektricheskimi stanciyami' [Draft tariff for electric energy supplied by central power plants], Trudy Vtorogo Vserossiiskogo elektrotekhnicheskogo s"ezda [Proceedings of the Second All-Russian Electrotechnical Congress], vol. 2, pp. 112-117.

Shelonskiy, N. (2014[1892]), Vmire budushchego [In the world of the future], Moscow: Prestige Book. 
Simonov, N. (2016), Razvitie elektroenergetiki Rossiiskoi imperii: predystoriya GOELRO [Development of the electric power industry of the Russian Empire: GOELRO prehistory], Moscow: Russian Foundation for Education and Science.

Smirnov, A. (1899-1900), 'Uspekhi sovremennoi elektrotekhniki' [The success of modern electrical engineering], Trudy Pervogo Vserossiiskogo elektrotekhnicheskogo s"ezda 1899-1900 v Sankt-Peterburge [Proceedings of the First All-Russian Electrotechnical Congress 1899-1900 in St. Petersburg], vol. 1, pp. 125-143.

Svinitskiy, V. (1902-1903), 'Sovremennoe sostoyanie russkoi elektrotekhnichekoi promyshlennosti v svyazi s ee tamozhennym voprosom i sposob razvitiya ee' [Current state of the Russian electrotechnical industry in connection with its customs issue and the way of its development], Trudy Vtorogo Vserossiiskogo elektrotekhnicheskogo s"ezda [Proceedings of the Second All-Russian Electrotechnical Congress], vol. 2, pp. 118-134.

Tyurin, V. (1902-1903), 'O priborakh, pozvolyayushchikh slepym chitat' obyknovennuyu pechat' i rukopisi' [On devices that allow the blind to read ordinary printing media and manuscripts], Trudy Vtorogo Vserossijskogo elektrotekhnicheskogo s"ezda [Proceedings of the Second All-Russian Electrotechnical Congress], vol. 3, pp. 65-80.

Umov, N. (1916), Collection of Works of Professor Nikolai Alekseevich Umov Published by Moscow Society of Natural Scientists and Ledentsov Society for Promoting the Success of Experimental Science and its Applications, Moscow: I. Kushnerev Printing House.

Zheltova, E. (1996), 'Elektrifikaciya Rossii (1921-1928): mifologicheskie aspekty' [Electrification of Russia (1921-1928): mythological aspects], Voprosy istorii, estestvoznaniya i tekhniki [Studies in the History of Science and Technology], no. 1, pp. 61-77.

Natalia Nikiforova is postdoctoral research fellow at the Poletayev Institute for Theoretical and Historical Studies in the Humanities, National Research University Higher School of Economics, Russian Federation. She received her PhD in cultural studies (Russian Candidate of Culturology) from the Herzen State Pedagogical University of Russia. Her research interests focus on the field of cultural history of the early electrification in Russia. 